Мацюхіна Т. Б. малодшы навуковы супращоўнік, Цэнтр даследаванняў беларускай культуры, мовы і літаратуры НАН Беларусі

\title{
НЕАРАМАНТЫЗМ У ТВОРАХ СУЧАСНЫХ БЕЛАРУСКІХ АЎТАРАЙ: ПРАБЛЕМЫ РЭЦЭПТЫЎНАЙ ЭСТЭТЫКІ (НА ПРЫКЛАДЗЕ ТВОРЧАСЦІ У. КАРАТКЕВІЧА, Л. РУБЛЕЎСКАЙ, В. ШНІПА)
}

У статті через призму неоромантизму аналізуються художні твори B. Короткевича, Л. Рублевской, В. Шнипа. Взаємодія читача $i$ автора, тексту $i$ интертекста розкривається по відношенню до певних способів у вираженні суті рецепиіі. Поетика художніх творів розглядається при детальному вивченні процесів сприйняття, розуміння і інтерпретації тексту. Асоціативність впливає на "горизонт очікуваня" читача і сприйняття ним художнього твору.

Ключові слова: неоромантизм, рецептивна поетика. 
В статье через призму неоромантизма анализируются художественные произведения В. Короткевича, Л. Рублевской, В. Шнипа. Взаимодействие читателя и автора, текста и интертекста раскрывается по отношению к определенным способам в выражении сущности рецепции. Поэтика художественных произведений рассматривается при детальном изучении прочессов восприятия, понимания и интерпретации текста. Ассоциативность влияет на "горизонт ожидания” читателя и восприятие им художественного произведения.

Ключевые слова: неоромантизм, рецептивная эстетика.

In the article through the prism of neoromantic works of art of V. Karatkevich, L. Rublevskaya, V. Shnip are analyzed. The interaction of the reader and the author, the text and intertext disclosed in relation to certain ways to express the essence of the reception. The poetics of works of art is considered at detailed studying of processes of perception, understanding and text interpretation. Associativity affect "the horizon of expectations" of the reader and his perception of the artwork.

Key words: neoromantic, reception aesthetics.

У сучасным беларускім літаратуразнаўстве неарамантызм часцей за ўсё разглядаецца як канцэпцыя мыслення, мастацкая плынь ці пэўная культуралагічна-эстэтычная ўласцівасць літаратурных твораў. Паводле У. Конана, “неарамантызм (ад неа... + рамантызм - “новы рамантызм”) - <..> назва асобных эстэтычных тэндэнцый і літаратурна-мастацкіх плыней, якія ўзніклі ў еўрапейскіх краінах канца 19-пачатку 20 ст., развівалі паэтыку і стылістыку рамантызму ў новых умовах" [Конан 1986: 58]. А у рэцэптыўнай эстэтыцы ўспрыманне мастацкіх тэкстаў неарамантычнай скіраванасці першачаргова вызначаецца высокімі ці нізкімі запатрабаваннямі грамадства, разумова-інтэлектуальным узроўнем адукаванасці чытача, усведамленнем задумы твора аўтарам.

Высокі ідэал неарамантыкаў выявіўся ў вобразе станоўчага, але неадназначнага па сваёй сутнасці лірычнага героя, які паказваецца як “актыўны, мужны і незвычайны чалавек высокай думкі і магутнай волі, проціпастаўлены інертнаму, мяшчанскаму побыту” [Конан 1986: 58]. Сярод такіх неарамантычных герояў У. Караткевіча варта назваць Андрэя Беларэцкага 3 “Дзікага палявання караля Стаха”, Алеся Загорскага з “Каласоў пад сярпом тваім...”. 
Менавіта для неарамантызму характэрная апора на класічны рамантызм у спалучэнні трагічнага і ўзвышанага. Яго ж сэнсавая знітаванасць 3 рэцэптыўнай эстэтыкай абумоўліваецца выкарыстаннем такіх спосабаў у выражэнні сутнасці рэцэпцыі, як “актуалізацыя”, “канкрэтызацыя”, “ідэнтыфікацыя” і інш. Такім чынам у межах неарамантызму фарміруецца незвычайны погляд на сутворчасць аўтара і чытача (рэцыпіента) - менавіта ў працэсе прачытання мастацкага твора - і на эстэтыку ўспрымання. Як сцвярджае Л. Брадзіс, сутворчасць стымулюецца рэцэптыўна-эстэтычнай актыўнасцю чытача, абумоўленай яго жыццёвым і мастацкім вопытам, здольнасцю да творчай фантазіi, асацыіравання, суперажывання і пераўвасаблення [Брадис 1991: 51].

У чым жа адметнасць літаратурных тэкстаў 3 неарамантычнай скіраванасцю? Па-першае, вялікае значэнне ў любым мастацкім творы надаецца нацыянальным вобразам, адметным характарам, актуальным пераважна для пэўнай краіны ці рэгіёну. Так, у паэзіі Л. Рублеўскай вылучаюцца наступныя вобразы каралевы Боны (верш “Паляванне каралевы Боны”), дойліда Казіміра Ждановіча (верш “Балада пра нясвіжскага дойліда”). Сусветна вядомым лічыцца герой паданняў і легенд - Машэка (верш “Машэка" У. Караткевіча). Па-другое, важная прысутнасць імёнаў, характараў сусветнага маштабу ў літаратуразнаўстве - В. Быкава (верш “Дрэва на Чатырдагу” У. Караткевіча), М. Стральцова (верш “Ўсё, што было, і ўсё, што часам сніцца...” У. Караткевіча), Еўфрасінні Полацкай (верш “Ефрасіння” Л. Рублеўскай), Ф. Скарыны (верш “Буслы Скарыны” В. Шніпа). Па-трэцяе, літаратурна-эстэтычны вопыт аўтара надае ягоным мастацкім тэкстам індывідуалізаваную, прыватную характарыстыку, а камунікацыя з чытачом ажыццяўляецца ў сімвалічна-знакавым абагуленым плане). Так, у вершы “Згінаюцца дрэвы ад подыху...” Л. Рублеўская адзначае: Здаециа мне, нашы азёры - // чароўныя дзверы // У лепшы, не здраджаны і не прададзены свет. // Туды саступае былое святое 
<...>. // Ў азёры сыходзяць будынкі, // звяры і бары... [Рублеўская 1990: 17].

Прадвызначанасць чытацкага светапогляду нярэдка існуе побач з абмежаванасцю ў выражэнні аўтарскага слова і аўтарскай волі, што звязана 3 жанравымі канонамі ў творчасці (“памяць жанра” М. Бахціна) і выкарыстаннем слоў, цытат, урыўкаў з тэксту іншага аўтара. Нягледзячы на права самастойнага, адкрытага выказвання пэўных тэарэтычна-аналітычных ідэй, пісьменнік абасоблены ў эстэтычна-выяўленчым плане мастацкімі сродкамі выразнасці, стылістычнымі прыёмамі і інш. Таму аўтар і чытач не заўсёды знаходзяць кропкі судакранання ў плане разуменння сэнсу твора.

Сэнс твора не заўсёды зразумелы чытачам і таму, што аўтар у сваёй творчасці можа выкарыстоўваць “чужыя” [Дранов 1992: 55] вобразы. Часцей за ўсё "чужыя” вобразы вынікаюць з разнароднасці мастацкіх кантэкстаў ці з прычыны катэгарычнага несупадзення i адрознасці эстэтычнага вопыта ў аўтараў аднаго напрамку, плыні, тэндэнцыі. Такім чынам, тэкст можа змяшчаць у сабе пэўныя ідэі пісьменнікаў і адначасова мець супрацьлеглы па сэнсе кантэкст.

Канкрэтызащыя мастацкага твора, - адзначае А. Дранаў, звязаная 3 імем Рамана Інгардэна і тлумачыцца як эстэтычная ўстаноўка чытача, функцыянальна падпарадкаваная задачы спасціжэння (разумення) літаратурнага твора [Дранов 1992: 63]. Эстэтычная каштоўнасць мастацкага твора ў рэцэптыўнай эстэтыцы вынікае з канкрэтнай, выразна патлумачанай задачы, якую ставіць перад сабою пісьменнік. У тым выпадку, калі аўтарскія ўяўленні пра твор супадаюць 3 чытацкім “гарызонтам чакання”, цалкам верагоднае вернае прачытанне літаратурнага шэдэўра і глыбіннае яго спасціжэнне праз інтэртэкст, а нярэдка і літаратурна-мастацкую парадыгму пэўнай эпохі. Неарамантызм жа ставіць акцэнт на ідэалізацыі і папулярызацыі героя, - таму “гарызонт чакання" тут узвышаны, недасяжны. 
Нездарма даследчык рэцэптыўнай эстэтыкі, нараталогіi, дэканструктывізму А. Дранаў падкрэслівае: канкрэтызацыя тэрмін рэцэптыўнай эстэтыкі, які абазначае працэс аднаўлення чытачом мастацкага твора, напаўнення “сэнсам” рамак мастацкай структуры шляхам запаўнення “пустых месцаў” сваімі ўяўленнямі і эмоцыямі на аснове ўласнага “гарызонта чакання” [Дранов 1992: 63]. У неарамантызме запаўненне “пустых месцаў” у мастацкім тэксце звязанае, аднак, з абстрагаваным вобразам лірычнага героя змагара, волата духу, актыўнага, дзейснага чалавека 3 такімі маральнымі каштоўнасцямі, як высакародства, смеласць, шчырасць, актыўнасць жыццёвай пазіцыі. У неарамантызме герой мастацкага твора набывае не ўласцівыя яму рысы, ідэалізуецца, паказваецца ў большай ступені дасканалым, чым ёсць на самай справе. Канкрэтызацыя вобраза лірычнага героя нярэдка спалучаецца 3 ідэнтыфікацыяй: Я нікому не здрадзіў, тым болей Радзіме, // Што мяне, нібы дым, над сабою падыме, // I схаваецица у дыме, нібыта агонь, // І жывой застанеция, і меч на далонь // Пакладзе, і вазьму я наш меч, і пайду // Родны дом бараніць < ..> [Шніп 2006: 197].

Ідэнтыффікаџыя, якая нярэдка сустракаецца ў творчасці неарамантыкаў, грунтуецца на сумяшчэнні вобразаў, якія існуюць у свядомасці аўтара i ўспрымаюцца чытачом як пэўны код. Даследчык А. Дранаў абапіраецца на ідэі В. Ізера і зазначае: ў працэсе прачытання тэксту ўзнікае такая форма ўдзелу чытача ў творы, калі ён “уцягваецца” ў тэкст настолькі, што яму здаецца, быццам дыстанцыя паміж ім і тым, што адбываецца ў творы, знікла [Дранов 1992: 55]. Ідэнтыфікацыя ў поўнай меры выявілася ў вобразна-выяўленчай паэзіі У. Караткевіча (вершы 'Месяц заснуў на коміне хаты...”, “Па-над шчыраю Шчарай, над шчодраю Шчарай...”), Л. Рублеўскай (вершы “Армагедон”, “Ціхая песня”), В. Шніпа (празаічныя мініяцюры філасофскага характару “Малако”, “Студня"; вершы "Вяртанне”, “Мы - апошнія дзеці Жанчыны...”). Названы тэрмін рэцэптыўнай эстэтыкі - 
ідэнтыфікацыя - закранае неарамантычныя пошукі ў рэчышчы нацыянальна-спецыфічнага і рэлігійна-асветніцкага светасузірання, а таксама ў плане вынаходніцтва культуралагічных каштоўнасцей: Усміхнуўся маладь друкар. // Кніга, нібы бусел, на руках // Разгарнула крыльь, каб лящещь. // Беларусь свяцілася у радках [Шніп 1983: 42].

Пры звароце да лірыкі Л. Рублеўскай i В. Шніпа заўважаецца тое, што тэматычны акцэнт тут змешчаны не на лірычным героі, а на ўніверсуме, яго ўласцівасцях і гарманічнай сутнасці самога свету (вершы “Кніга лёсаў”, “Страла”, “Хто выдумаў, што чалавек...", "Пад ссохлым лістом задрамала..." Л. Рублеўскай; “Мастак намалюе неба...”, “...На вадзе не запісаць малітву...”, “Вярнуцца дадому, нібыта прачнуцца...” В. Шніпа). У паэзіі ж У. Караткевіча павышаная роля станоўчага, ідэалізаванага героя, актуальныя яго запатрабаванні да грамадства (вершы “Старажытны беларус”, “Мастакам”). У творчасці названага пісьменніка вялікае значэнне надаецца выяўленню псіхічных працэсаў, спецыфікі мыслення лірычных герояў: Tы $i$ я: пралеска $\check{y}$ снах бурану, // Дрэуца вішні ў ярасным агні, // Кропля на спіне Левіяфана, // Радуга на крылах навальніч [Караткевіч 1987: 184]. А. Дранаў лічыць: калі працэс прачытання супадае 3 працэсам выпрацоўкі віртуальных вымярэнняў тэксту, то можа ўзнікнуць (згодна з Ізерам) уражанне, што чытач як быццам прыўздымаецца над вобразамі твора [Дранов 1992: 161]. Мастацкія творы У. Караткевіча, Л. Рублеўскай, В. Шніпа раскрываюць своеасаблівасць бачання соцыуму і космасу ў іх цеснай знітаванасці між сабою праз прызму неарамантычных каштоўнасцей - Радзімы, унутранай свабоды і кахання. Айчына, малая радзіма, родны кут як канцэпты каштоўнасныя ў творчасці У. Караткевіча (вершы “Бацькаўшчына”, “Буслы вучаць дзяцей”), У. Рублеўскай (вершы “Апошні беларускі князь”, “Немата”), В. Шніпа (верш “Я нікому не здрадзіў, тым болей - Радзіме...”). 
Пэўная ступень супадзення чытацкага і аўтарскага светапоглядаў у дыялагічнай культуры мае дачыненне да працэсаў уздзеяння, успрымання, разумення і інтэрпрэтацыі тэксту. Дадзены факт абумоўліваецца “гарызонтам чакання” рэцыпіента - таго, хто слухае, чытае ці аналізуе самастойна тэкст. "Гарызонт чакання" вытлумачваецца як комплекс эстэтычных, сацыяльна-палітычных, псіхалагічных і іншых уяўленняў, якія абумоўліваюць адносіны аўтара i твора да грамадства (і да разнастайных відаў чытацкай аўдыторыі), а таксама адносіны чытача да твора $<\ldots>$ [Дранов 1992: 33]. Як бачым, “гарызонт чакання” мае пэўнае дачыненне да засваення інфармацыі чытачом i яе пераапрацоўкі 3 мэтаю мастацкага ўздзеяння і прагнозу актуальнасці твора ў будучыні. Пазнавальная і прагназуючая функцыі літаратуры прадвызначаюць у неарамантызме пэўныя матывы - містыкі, прыгодніцтва, свабоды, адзіноты, пошуку свайго жыццёвага шляху, кахання і інш.

Наданне значнасці нацыянальна-гістарычнаму мастацкаму вобразу, яго вытлумачэнне ў тэксце і вылучэнне ў ім адметных складнікаў па тыпалогіі ці ў кантрасце, складаюць асноўны змест рэцэптыўнай эстэтыкі ў неарамантызме (верш “Шляхціц Завальня" Л. Рублеўскай). Актуалізацыя, заснаваная на "разгортванні" зрокавых, слыхавых, кінестэтычных вобразаў праз асацыятыўнасць, спараджае новую, унікальную інтэрпрэтацыю мастацкага тэксту. Зрокавая суаднесенасць вобразаў, якія ўзнікаюць у свядомасці аўтара, і асацыяцый ад іх спараджае пэўную дыстанцыю ці яе адсутнасць паміж аўтарам і чытачом. Гэтай жа задачы спрые i выкарыстанне ў тэксце рэмінісцэнцый, алюзій, цытат, дзякуючы чаму лірычны герой набліжаецца ці аддаляецца ад аўтара.

Відавочна, неарамантыкі, у адрозненне ад мадэрністаў, упарта i напружана шукалі пазабуржуазныя шляхі адраджэння гуманізму, сцвярджэння чалавечай індывідуальнасці, цэласнай асобы [Царик 1984: 30]. Менавіта таму эстэтычная дыстанцыя паміж мастацкім творам і чытачом у творчасці У. Караткевіча, Л. Рублеўскай, В. Шніпа падразумявае пэўную стратэгію тэксту, 
асабліва ў неарамантычным кірунку, у выніку чаго ён набывае прыкмету адназначнасці / мнагазначнасці. Мастацкі твор не заўсёды трактуецца адназначна, паколькі ў ім нярэдка спалучаюцца некалькі ліній развіцця дзеяння, фабул, а погляд аўтара на тэкст часам не супадае з ўласным эстэтычным вопытам.

Гуманнае стаўленне да рэчаіснасці і асновы касмалагічных і касмаганічных законаў пабудовы свету раскрываюцца дзякуючы эстэтычнаму вопыту аўтараў-неарамантыкаў. У аснове ж эстэтычнага вопыту беларускіх пісьменнікаў У. Караткевіча, Л. Рублеўскай, В. Шніпа знаходзяцца назапашаныя веды грамадства за пэўны прамежак часу, уласны досвед па пэўных пытаннях, мастацкі густ і літаратурна-мастацкая канцэпцыя.

\section{БІБЛІЯГРАФІЯ}

Брадис 1991 - Брадис Л. В. Сотворчество / Л. В. Брадис // Художественное восприятие. Основные термины и понятия / Гос. комитет РСФСР по делам науки и высш. школы, ТГУ. - Тверь : ТГУ, 1991. - С. 50-53.

Дранов 1992 - Дранов А. В. Горизонт ожидания / А. В. Дранов // Терминология современного зарубежного литературоведения / М. : РАН, ИНИОН, 1992. - С. 33-36.

Дранов 1992 - Дранов А. В. Идентификация / А. В. Дранов // Терминология современного зарубежного литературоведения / М.: РАН, ИНИОН, 1992. - С. 54-56.

Дранов 1992 - Дранов А. В. Конкретизация / А. В. Дранов // Терминология современного зарубежного литературоведения / М. : РАН, ИНИОН, 1992. - С. 63-65.

Дранов 1992 - Дранов А. В. Стратегия текста / А. В. Дранов // Терминология современного зарубежного литературоведения / М. : РАН, ИНИОН, 1992. - С. 159-162.

Караткевіч 1987 - Караткевіч У. Збор твораў: у 8 т. Т. 1. Вершы, паэмы / [Аўт. прадм. В. Быкаў]. - Мінск : Маст. літ., 1987. - 431 с.

Конан 1986 - Конан У. М. Неарамантызм / У. М. Конан // Энцыклапедыя літаратуры і мастацтва Беларусі: у 5 т. Т. 4. Накцюрн-Скальскі / Рэдкал.: І. П. Шамякін (гал. рэд.) [i інш.]. - Мінск : БелСЭ, 1986. - С. 58.

Рублеўская 1990 - Рублеўская Л. Крокі па старых лесвіцах / Л. Рублеўская. Мінск: выд-ва ЦК КП Беларусі, 1990. - 48 с.

Царик 1984 - Царик Д. К. Типология неоромантизма / Д. К. Царик. - Кишинев : "Штиинца", 1984. - 167 с.

Шніп 2006 - Шніп В. А. Балада камянёў: паэзія і проза / В. А. Шніп. - Мінск: Маст. літ., 2006. -318 с.

Шніп 1983 - Шніп В. А. Гронка святла: вершы / В. А. Шніп. - Мінск: Маст. літ., 1983. $-54 \mathrm{c}$.

Стаття надійшла 20 вересня 2013 р. 